\title{
Factors associated with the consumption of fruits and vegetables in schoolchildren aged 7 to 14 years of Florianópolis, South of Brazil ${ }^{1}$
}

\author{
Fatores associados ao consumo de frutas, legumes \\ e verduras em escolares de 7 a 14 anos do \\ município de Florianópolis
}

Carla Regina GALEGO2

Gisele Liliam D'AVILA²

Francisco de Assis Guedes de VASCONCELOS²

A B S T R A C T

\section{Objective}

To estimate the prevalence of the fruit and vegetable intake of schoolchildren aged 7 to 14 years from Florianópolis, Santa Catarina, Brazil, and analyze the associated factors.

\section{Methods}

This cross-sectional study analyzed food intake, socioeconomic, and biological data of 2,836 schoolchildren. The Chi-square test analyzed the dependent (fruit and vegetable intake) and independent variables; the latter with $p$-value $<0.20$ were selected for logistic regression analysis. The level of significance was $p<0.05$.

\section{Results}

Only $4.8 \%$ of the sample had adequate fruit and vegetable intake. The variables associated with adequate fruit and vegetable intake were school ownership status (private versus public), mother's education level, and family income per member. After adjustment only family income per capita remained associated with fruit and vegetable intake.

\section{Conclusion}

The fruit and vegetable intake of schoolchildren aged 7 to 14 years from Florianópolis, Santa Catarina, Brazil, is inadequate.

Indexing terms: Adolescent. Child. Food consumption. Fruit. Vegetables.

1 Article based on the master's thesis of CR GALEGO intitled "Fatores associados ao consumo de frutas, legumes e verduras em escolares de 7 a 14 anos do município de Florianópolis, Santa Catarina". Universidade Federal de Santa Catarina; 2010.

2 Universidade Federal de Santa Catarina, Centro de Ciências da Saúde, Programa de Pós-Graduação em Nutrição. R. Delfino Conti, s/n., Trindade, 88040-900, Florianópolis, SC, Brasil. Correspondência para/Correspondence to: FAG VASCONCELOS.

E-mail: <f.vasconcelos@ufsc.br>.

Support: Conselho Nacional de Desenvolvimento Científico e Tecnológico (Process number 402322/2005-3). 


\section{RE S U M O}

\section{Objetivo}

Estimar a prevalência e analisar os fatores associados ao consumo de frutas, legumes e verduras em escolares de 7 a 14 anos de idade do município de Florianópolis, Santa Catarina.

\section{Métodos}

Estudo transversal com amostra probabilística de 2836 escolares. Foram analisadas variáveis de consumo alimentar, biológicas e socioeconômicas. Foi aplicado teste Qui-quadrado entre as variáveis independentes e dependentes (consumo de frutas, legumes e verduras), sendo aquelas com valor de $p<0,20$ incluídas na análise de regressão logística. O nível de significância adotado foi de $p<0,05$.

\section{Resultados}

O consumo adequado de frutas, legumes e verduras foi verificado em 4,8\% da amostra. As variáveis associadas com o consumo adequado de frutas, legumes e verduras foram o tipo de escola, nível de escolaridade da mãe e renda familiar per capita. Após o ajuste, apenas a renda familiar per capita manteve a associação.

\section{Conclusão}

Verificou-se que o consumo de frutas, legumes e verduras por escolares de 7 a 14 anos de idade residentes no município de Florianópolis encontra-se abaixo das recomendações.

Termos de indexação: Adolescente. Criança. Consumo de alimentos. Frutas. Verduras.

\section{INTRODUCTION}

Both developed and developing countries consider that low Fruit and Vegetable (FV) intake increases the risk of chronic Non-Communicable Diseases $(N C D)^{1,2}$. The literature provides evidence that adequate $\mathrm{FV}$ intake protects against the risk of NCD, such as diabetes Mellitus type 2, cardiovascular diseases, dyslipidemia, chronic respiratory diseases, hypertension, and some types of cancer ${ }^{3}$. NCD are the main global cause of mortality and disability. The World Health Organization (WHO) estimates that NCD kill 36 million people annually. In 2007 NCD accounted for $72 \%$ of the deaths in Brazil ${ }^{4}$.

Inadequate fruit and vegetable intake in children and adolescents has been evidenced by Brazilian $^{5-8}$ and foreign studies ${ }^{9,10}$.

The Pesquisa Nacional de Saúde do Escolar (PeNSE, National Schoolchild Health Survey) conducted in 2009 by the Instituto Brasileiro de Geografia e Estatística (IBGE, Brazilian Institute of Geography and Statistics) surveyed 60,973 students aged 13 to 15 years, attending public and private schools throughout the country, and also found low FV intake ${ }^{11}$. A total of $34.3 \%$ of the ninth graders attending private schools and $30.4 \%$ of those attending public schools had consumed vegetables on five days of the study week. Fruits had been consumed five days a week or more by $31.5 \%$ of the schoolchildren ${ }^{11}$.

The 2012 Pesquisa Nacional de Saúde do Escolar surveyed 109,104 students aged 13 to 15 years and again found low FV intake: $43.4 \%$ and $30.2 \%$ of the schoolchildren consumed vegetables and fruits, respectively, weekly ${ }^{12}$.

In Santa Catarina, Costa et al. ${ }^{6}$ studied 4,964 schoolchildren aged 6 to 10 years and found that only $2.7 \%$ of the sample had adequate FV intake ( $>5$ times a day), and that $26.6 \%$ had not consumed any FV on the study day.

In Florianópolis (SC), Costa et al. ${ }^{7}$ studied 4,168 children aged 7 to 10 years to assess dietary changes after a five-year period (2002 and 2007) and found that the FV intake of children attending public and private schools decreased significantly by $22.9 \%$ and $27.8 \%$, respectively, going from $90.1 \%$ in 2002 to $69.5 \%$ in 2007 for the former and from $94.1 \%$ in 2002 to $67.9 \%$ in 2007 for the latter.

The growing prevalence of obesity in children and adolescents ${ }^{13-15}$ emphasizes the 
importance of promoting a healthy lifestyle, including higher $\mathrm{FV}$ intake ${ }^{9}$. The nutritional basis behind the recommendation of higher FV intake is the possibility of FV replacing low-nutrient, energy-dense foods, such as refined grains and sugar, basic ingredients in processed and fast foods. In addition to their contribution to energy balance, they may also provide nutrients that benefit general health significantly ${ }^{16}$.

The "Brazilian Food Guide" published in 2006 by the Ministry of Health recommends 3 servings of fruits and 3 servings of vegetables a day to prevent $\mathrm{NCD}^{17}$. The $\mathrm{WHO}^{18}$ recommends a minimum FV intake of 400 grams a day. Global strategies to promote health and encourage higher FV intake began in the early 1990s; one such strategy is the 5-a-Day Program, which recommends $5 \mathrm{FV}$ servings a day ${ }^{19,20}$.

The World Health Organization encourages high FV intake to protect and promote health and healthy food habits, improving quality of life and decreasing NCD risk ${ }^{1}$. Knowledge about the importance of FV intake is critical, since childhood habits may persist throughout adulthood ${ }^{6}$.

Given the scarcity of studies on the FV intake of children and adolescents, the objective of this study was to estimate the prevalence and analyze the factors associated with FV intake in schoolchildren aged 7 to 14 years from Florianópolis (SC).

\section{METHODS}

This cross-sectional study investigated a probabilistic sample of schoolchildren aged 7 to 14 years attending private and public schools in Florianópolis (SC). Data were collected 2007. The study was sponsored by the Conselho Nacional de Desenvolvimento Científico e Tecnológico (CNPq - National Council for Scientific and Technological Development) (Process number 402322/2005-3).

The methods used for determining sample size and sampling are described elsewhere ${ }^{13}$. In summary, sample size was based on a prevalence of obesity of $10 \%$ for children aged 7 to 10 years ${ }^{21}$ and of $17 \%$ for children aged 11 to 14 years $^{22}$, an error margin of $2 \%$, and a design effect of 1.3 , resulting in a sample size of 2,800 schoolchildren, 1,100 seven- to ten-year-olds and 1,700 eleven- to fourteen-year-olds. Considering a sample loss of $10 \%$, the final sample should include 3,100 schoolchildren aged 7 to 14 years. Sampling consisted of two stages. In the first stage, the schools in Florianópolis (SC) were stratified by location (North, South, East, downtown, and continent) and ownership status (public or private). Schools in each geographical stratum were selected randomly, with probability proportional to stratum size. Thus, 11 public and 6 private schools were selected from the 87 schools in the municipality, 33 private and 54 public. In the second stage, the schoolchildren were randomly selected by age group, with equal probability, in each of the selected schools. The analyses to estimate prevalence and associated factors considered both the design effect and sampling plan. A total of 2,863 schoolchildren were surveyed. Children aged less than seven years $(n=15)$ and more than fourteen years $(n=12)$ were excluded, resulting in a sample size of 2,836 (99\%) schoolchildren.

The study collected biological (gender, age, weight, and height), socioeconomic (family income, mother's education level, and school ownership status), and food intake (FV intake) data.

Gender, age, and school ownership status were collected from the lists provided by the schools, which were included in the questionnaire by a data pre-collection team. Socioeconomic data, such as family income and mother's education level, were collected by a self-administered questionnaire sent to the children's parents or guardians.

Anthropometric data were collected by trained anthropometrists as recommended by the $\mathrm{WHO}^{23}$ and Lohman et al. ${ }^{24}$. This procedure allowed assessment of intra- and interpersonal measurement differences by calculating the Technical Error of Measurement (TEM) $)^{25}$. 
Body weight was measured by the electronic scale Marte ${ }^{\circledR}$ model PP 180 (Marte Balanças e Aparelhos de Precisão Ltda, São Paulo, Brazil), with a capacity of $180 \mathrm{~kg}$ and accuracy of 50 grams. Height was measured by the stadiometer Alturexata ${ }^{\circledR}$ (Alturexata Ltda, Belo Horizonte, Brazil), with an accuracy of $1 \mathrm{~mm}$.

The nutritional status of the schoolchildren was given by Body Mass Index (BMI) - for-age and gender, according to Cole et al. ${ }^{26}$, as proposed by the International Obesity Task Force. BMI was calculated by dividing the weight in kilograms by the square of the height in meters. The children were then grouped into two groups: not overweight/obese and overweight/obese.

The independent variables were age group (children aged 7 to 9 years, adolescents aged 10 to 14 years); gender (male, female); mother's education level (never attended school or incomplete elementary school; complete elementary school or incomplete high school; complete high school or incomplete higher education; and complete higher education); family income per member (quartiles in reais); and school ownership status (private, public).

The Questionário Alimentar do Dia Anterior (QUADA, Previous Day Food Questionnaire) ${ }^{27}$ questionnaire collected the foods consumed on the preceding day by the children. This 24-hour recall is validated and structured to assess the food intake of schoolchildren on a single day. The instrument layout and protocol were developed by dieticians, educators, and artists, taking into account age-related cognitive skills and ease of administration. The meals, foods, and food groups listed in the questionnaire are based on the dietary habits of these age groups, on the foods in the Programa Nacional de Alimentação Escolar (PNAE, National School Food Program's) menu, and those in the "Brazilian Food Guide"27,17.

The questionnaire contains the illustration of 21 foods in four A4 paper sheets, structured into six daily meals (breakfast, morning snack, lunch, afternoon snack, supper, and bedtime snack). This allows identifying the proportion of schoolchildren who ate the 21 foods in the six meals of the preceding day, which can be assessed qualitatively by determining the nutritional profile represented by the different nutrient sources in each food group ${ }^{27}$.

The students were informed that they would have to recall everything they ate the day before to fill out the questionnaire. Therefore, the team repeatedly mentioned the day before, and informed the students of meal times. The questionnaires with the students' names were given to the students by the research team and their teachers, who clarified eventual doubts discreetly to avoid distracting others. After the instruments were handed out, each having banners describing each meal and drawings of the foods according to the questionnaire, the research team read the following questions to the students: What did you eat yesterday? For breakfast? For the morning snack? For lunch? For the afternoon snack? For supper? For the bedtime snack? After each question, the students were asked to look carefully at the foods and circle those that they had consumed in that meal. The students were also told that if they had not had that particular meal, they should not circle any food; and that they should circle FV if they had consumed preparations containing FV.

The outcome variable was FV intake determined by QUADA and grouped as follows: adequate when intake was equal to or higher than five times a day and inadequate when intake was less than five times a day, as recommended by the 5-a-Day Program ${ }^{19,20}$. FV intake by the study sample was analyzed as follows: fruit intake; vegetable intake; and FV intake. Fruit intake was adequate when equal to or greater than two times a day, and vegetable intake was adequate when equal to or greater than three times a day.

A database was created in the software EpiData 3.2 and fully checked by trained data entry operators. Consistency and amplitude were checked automatically.

The data were treated by the software Stata version 9.0. The distribution of the population 
by socioeconomic and biological variables is described statistically by frequency distribution tables. The Chi-square test $\left(\chi^{2}\right)$ measured the association between the independent (gender, age, family income per capita, mother's education level, and school ownership status) and dependent (FV intake) variables. All variables with $p<0.20$ in the $\chi^{2}$ were included in unconditional multiple regression analysis. The prevalence ratios were estimated along with their respective crude and adjusted $95 \%$ Confidence Intervals (95\% Cl). The Mann-Whitney test compared FV intake between the overweight/obese and nonoverweight/obese groups.

The design effect was taken into account in all analysis by using Stata's svy command, which analyzes data from complex samples. Associations with $p$-value $<0.05$ were considered significant.

The study protocol was approved by the Human Research Ethics Committee of the Universidade Federal de Santa Catarina ( ${ }^{\circ}$ 028/2006). The subjects were included in the study after their parents or guardians signed an Informed Consent Form.

\section{RES U L T S}

Of the 2,836 study schoolchildren, 1,478 $(52.1 \%)$ were females, and 2,315 (75.3\%) attended public schools. A total of 899 (32.8\%) mothers had completed high school or some higher education. The family income per member of $722(29.8 \%)$ schoolchildren was in the first quartile ( $\leq 540.00$ reais) (Table 1). The mean age and standard deviation of the children was
$11.3 \pm 2.2$ years, the minimum age was 7 years and the maximum, 14 years. According to BMI, $2232(78.0 \%)$ schoolchildren were not overweight/obese and 629 (22.0\%) were overweight/obese.

Nearly everyone ( $n=2,700,95.2 \%)$ had inadequate $\mathrm{FV}$ intake ( $<5$ times a day). Moreover, 990 (34.9\%) students reported not having eaten $\mathrm{FV}$ the day before. Fruits and vegetables were not

Table 1. Absolute and percentage distribution of the study schoolchildren aged 7-14 ( $n=2,836)$ by independent variables. Florianopolis (SC), Brazil, 2007.

\begin{tabular}{lcc}
\hline Variables & $\mathrm{n}$ & $\%$ \\
\hline Gender & & \\
Female & 1,478 & 52.1 \\
Male & 1,358 & 47.9 \\
School ownership status & & \\
Public & 2,135 & 75.3 \\
Private & 701 & 24.7 \\
Age (years) & & \\
Children (7-9) & & \\
Adolescents (10-14) & 909 & 32.09 \\
Mother's education level & 1,924 & 67.91 \\
IES & & \\
CES & 692 & 25.2 \\
CHS & 545 & 19.9 \\
CHE & 899 & 32.8 \\
Family income per capita (reals) & 605 & 22.1 \\
$1^{\text {st }}$ quartile ( $\left.\leq 540.00\right)$ & & \\
$2^{\text {nd }}$ quartile (540.01 to 1,000.00) & 529 & 21.8 \\
$3^{\text {rd }}$ quartile (1,000.01 to 2,000.00) & 580 & 23.9 \\
$4^{\text {th }}$ quartile (<2,000.00) & 592 & 24.5 \\
\hline
\end{tabular}

Note: IES: Incomplete Elementary School or never attended school; CES: Complete Elementary School or incomplete high school; CHS: Complete High School or incomplete higher education; CHE: Complete Higher Education.

Table 2. Absolute and percentage distribution, Confidence Interval of $95 \%(95 \% \mathrm{Cl})$, mean, and Standard Deviation (SD) of adequate Fruit and Vegetable (FV) intake by students aged 7-14 years ( $n=2,836)$ by food group. Florianopolis (SC), Brazil, 2007.

\begin{tabular}{|c|c|c|c|c|c|c|}
\hline \multirow{2}{*}{ Food groups } & \multicolumn{2}{|c|}{ Adequate intake } & \multirow{2}{*}{$95 \% \mathrm{Cl}$} & \multirow{2}{*}{ Mean } & & \multirow{2}{*}{ SD } \\
\hline & $n$ & $\%$ & & & & \\
\hline Fruits & 543 & 19.2 & $15.5-22.8$ & 0.8 & \pm & 1.0 \\
\hline Vegetables & 144 & 5.1 & $4.1-6.1$ & 0.7 & \pm & 1.0 \\
\hline FV & 135 & 4.8 & $3.7-5.9$ & 1.5 & \pm & 1.6 \\
\hline
\end{tabular}


consumed by 1,531 (54.0\%) and 1,602 (56.5\%) schoolchildren, respectively.

Only 135 (4.8\%) schoolchildren had adequate $\mathrm{FV}$ intake $(95 \% \mathrm{Cl}=3.7-5.9 \%)$. FV, fruits, and vegetables were consumed a mean of $0.8 \pm 1.0,0.7 \pm 1.0$, and $1.5 \pm 1.6$ times a day, respectively (Table 2 ).

The fruit $(p=0.220)$, vegetable $(p=0.25)$, and FV ( $p=0.250)$ intakes of overweight/obese and non-overweight/obese children did not differ. The medians for fruit and vegetable intakes were zero, regardless of nutritional status. On the other hand, the median FV intake was 1 in both groups.

Table 3 shows the crude and adjusted prevalence ratios of the study associations. The variables associated with adequate FV intake were school ownership status, mother's education level, and family income per member. The mother's education level was positively associated with FV intake in the intermediate education level strata (complete high school or incomplete higher education, $p=0.027$; complete elementary school or incomplete high school, $p=0.04$ ).

Variables with $p<0.20$ (school ownership status, mother's education level, and family income per member) were included in the adjusted analysis model. After adjustment, the only variable associated with outcome was family income per member (Table 3).

\section{DISCUSSION}

The study found that only $4.8 \%$ of the schoolchildren had adequate FV intake. This finding is concerning and indicates the need of creating and reassessing strategies that focus on a healthier diet for this population.

Table 3. Distribution of prevalence, Prevalence Ratio (PR), crude and adjusted Confidence Interval of $95 \%(95 \% \mathrm{Cl})$, and $p$-value of the association between adequate fruit and vegetable intake and the independent variables of schoolchildren aged 7-14. Florianopolis (SC), Brazil, 2007.

\begin{tabular}{|c|c|c|c|c|c|}
\hline \multirow{2}{*}{ Variables } & \multirow{2}{*}{$\%(95 \% \mathrm{Cl})$} & \multicolumn{2}{|c|}{ Crude } & \multicolumn{2}{|c|}{ Adjusted $^{*}$} \\
\hline & & PR $(95 \% \mathrm{Cl})$ & $p$-value & PR $(95 \% C l)$ & $p$-value \\
\hline \multicolumn{6}{|l|}{ Gender } \\
\hline Male & $5.0(3.0-7.0)$ & 1 & & & \\
\hline Female & $4.5(3.4-5.7)$ & $0.90(0.5-1.5)$ & 0.670 & - & - \\
\hline \multicolumn{6}{|l|}{ School ownership status } \\
\hline Public & $4.3(3.1-5.4)$ & 1 & & & \\
\hline Private & $6.3(3.0-9.6)$ & $1.50(0.8-2.5)$ & 0.126 & - & - \\
\hline \multicolumn{6}{|l|}{ Age (years) } \\
\hline $7-9$ & $4.7(2.8-6.7)$ & 1 & & & \\
\hline $10-14$ & $4.7(3.2-6.3)$ & $1.00(0.5-1.8)$ & 0.337 & - & - \\
\hline \multicolumn{6}{|l|}{ Mother's education level } \\
\hline $\mathrm{CHE}$ & $6.5(4.3-8.6)$ & 1 & & & \\
\hline $\mathrm{CHS}$ & $4.3(2.8-5.9)$ & $0.66(0.4-0.9)$ & 0.027 & - & - \\
\hline CES & $4.0(2.8-5.3)$ & $0.61(0.3-0.9)$ & 0.040 & - & - \\
\hline IES & $4.9(2.8-5.3)$ & $0.75(0.4-1.4)$ & 0.350 & - & - \\
\hline \multicolumn{6}{|l|}{ Family income per capita (reais) } \\
\hline $4^{\text {th }}$ quartile $(<2000.00)$ & $6.9(4.3-9.6)$ & 1 & & 1 & \\
\hline $3^{\text {rd }}$ quartile (1000.01-2000.00) & $3.5(1.9-5.0)$ & $0.48(0.2-0.8)$ & 0.019 & $0.48(0.2-0.8)$ & 0.019 \\
\hline $2^{\text {nd }}$ quartile (540.01-1000.00) & $3.2(2.3-4.2)$ & $0.45(0.2-0.7)$ & 0.007 & $0.45(0.2-0.7)$ & 0.007 \\
\hline $1^{\text {st }}$ quartile $(\leq 540.00)$ & $5.4(2.7-8.1)$ & $0.77(0.7-1.4)$ & 0.382 & $0.77(0.7-1.4)$ & 0.382 \\
\hline
\end{tabular}

Note: ${ }^{*}$ The adjusted analysis contains the variables with $p$-values $<0.20$.

CHE: Complete Higher Education; CHS: Complete High School or incomplete higher education; CES: Complete Elementary School or incomplete high school; IES: Incomplete Elementary School or never attended school. 
Low fruit and vegetable intake in schoolchildren was also found by another Brazilian cross-sectional study of 390 adolescents aged 10 to 17 years conducted by Toral et al. ${ }^{28}$ in Piracicaba (SP), which reported that roughly $28 \%$ of the adolescents did not reach the minimum intake of 3 servings of fruits and 3 servings of vegetables a day, as recommended by the Brazilian Ministry of Health's "Brazilian Food Guide"17.

In agreement with these data, a study conducted by Costa et al. ${ }^{6}$ in 8 municipalities of Santa Catarina with 4,964 schoolchildren aged 6 to 10 years found that $F V$ were consumed a mean of 1.5 times/day; that only $2.7 \%$ of the sample had adequate FV intake ( $\geq 5$ times per day); and that $26.6 \%$ had not consumed FV the day before.

Low fruit and vegetable intake was also found by Assis et al. ${ }^{5}$ when they studied the food intake of 1,232 schoolchildren aged 7 to 10 years from Florianópolis (SC): $27.2 \%$ consumed fruits three times a day, $5.5 \%$ consumed vegetables two times a day, and $15 \%$ consumed FV five times a day.

Riediger et al. ${ }^{9}$ studied 18,524 Canadian adolescents aged 12 to 19 years and found that almost $60 \%$ of them consumed FV less than five times a day.

Likewise, Pérez-Lizaur et al. ${ }^{10}$ found that only $11.0 \%$ of 327 Mexican children aged 7 to 10 years consumed fruits three or more times a day, indicating low FV intake, and that girls consumed more $\mathrm{FV}$ than boys $(15.2 \%$ and $6.7 \%$, respectively).

The fruit and vegetable intake of the study overweight/obese and non-overweight/obese groups did not differ. Fagundes et al. ${ }^{29}$ studied 218 children and adolescents aged 6 to 14 years from Parelheiros, a neighborhood in the municipality of São Paulo, and found that the obese, followed by the overweight, had the lowest FV intakes.

Hassapidou et al. ${ }^{30}$ studied 512 Greek adolescents aged 11 to 14 years and found that overweight/obese adolescents adhered more to the Western diet and less to the traditional Mediterranean diet than normal weight adolescents. Overweight/obese adolescents consumed less fruits $(p<0.001)$, leaf vegetables $(p<0.001)$, and non-leaf vegetables $(p<0.001)$ than normal weight adolescents.

In the present study, mother's education level and family income by member were associated with $\mathrm{FV}$ intake.

The association between parents' education level and FV intake was also found by other studies ${ }^{9,31}$. Godoy et al. ${ }^{31}$ studied 437 male and female adolescents from the neighborhood of Butantã, municipality of São Paulo, aged 12 to 19 years and found that $F V$ intake increased with the education level of the family head. The authors concluded that higher education level leads to better food-related knowledge, increasing food variety and promoting higher FV intake. Additionally, the present study found that adolescents in the fourth quartile of family income per member consumed significantly more $\mathrm{FV}$ than those in other quartiles.

A study of 18,524 Canadian adolescents aged 12 to 19 years found that family income was significantly associated with FV intake $(p<0.001)$, and that higher parents' education level was associated with higher FV intake frequency $(p<0.001)^{9}$.

Similarly, Kristjansdottir et al. ${ }^{32}$ studied 1,179 Icelandic adolescents and found that the parents' socioeconomic level was positively associated with the FV intake of boys $(p=0.04)$ but not of girls $(p=0.43)$, and with the fruit intake of girls $(p<0.01)$ but not of boys $(p=0.25)$.

Toral et al. ${ }^{28}$ studied 390 adolescents aged 10 to 17 years from São Paulo but did not find differences in $\mathrm{FV}$ intake by gender.

Instituto Brasileiro de Geografia e Estatística 2009 PeNSE survey of 60,973 students aged 13 to 15 years found that vegetable intake was not affected by gender (31.3\% for females and $31.2 \%$ for males); in state capitals and the Federal 
District, $31.5 \%$ of the sample consumed fruits five or more days a week, regardless of gender ${ }^{8}$.

A study with Canadian adolescents aged 12 to 19 years found that the percentage of girls (31\%) who consumed fruits two to four times a day was significantly higher than that of boys $(26 \%)(p<0.05)$. The percentage of girls $(41 \%)$ who consumed FV five to ten times a day was also significantly higher than that of boys (35\%) $(p<0.05)^{9}$.

The present study did not find association between age and outcome, contrary to a Canadian study of adolescents aged 12 to 19 years that found significantly different fruit $(p<0.05)$ and FV $(p<0.001)$ intakes between two age groups ${ }^{9}$.

One of the study limitations was the use of FV intake frequency (times per day), considering adequate an intake frequency equal to or greater than five times a day. As mentioned earlier, the Brazilian Ministry of Health ${ }^{17}$ and the $\mathrm{WHO}^{18}$ recommend intake in grams and number of servings, respectively. Thus, this methodological strategy may have over- or underestimated FV intake. However, other studies have used 'FV intake frequency (times per day)' as proxy of 'number of FV servings per day'5-7.

Another limitation regards the use of QUADA to investigate FV intake, a questionnaire based on the 24-hour recall ${ }^{27}$. The present study used the questionnaire for assessing a single food intake day of the schoolchildren, which may estimate a day's FV intake accurately, but not the habitual FV intake. However, single-day assessment has been proven adequate and is often preferred by some studies, especially those that involve large, complex samples $6,7,23,33$.

\section{CONCLUSION}

Schoolchildren aged 7 to 14 years from the municipality of Florianópolis (SC) do not meet the FV intake recommended by the 5-a-Day
Program. Of the study variables, only family income per capita was associated with FV intake.

More knowledge is needed about the FV intake of children and adolescents and its associated factors, which can then be used for guiding and implementing local health policies that encourage FV intake, promoting healthy eating practices and consequently, preventing NCD.

\section{A C KNOWLEDGEMENTS}

We thank Conselho Nacional de Desenvolvimento Científico e Tecnológico for sponsoring the study.

\section{CONTRIBUTORS}

CR GALEGO analyzed and interpreted the results and wrote the manuscript. GL D'AVILA wrote and reviewed the manuscript. FAG VASCONCELOS conceived the study, and structured and reviewed the manuscript.

\section{REFERE NCES}

1. Organização Mundial da Saúde. Documento informativo para o workshop de Lisboa sobre a promoção de hortifrutícolas nos países de expressão portuguesa. Lisboa: OMS; 2006 [acesso 2013 jun 20]. Disponível em: <http://apps.who.int/iris/ handle/10665/43416>

2. Castanho F, Marsola FC, Mclellan KCP, Nicola M, Moreto F, Burini RC. Consumo de frutas, verduras e legumes associado à síndrome metabólica e seus componentes em amostra populacional adulta. Ciênc Saúde Colet. 2013; 18(2):385-92. doi: 10.15 90/S1413-81232013000200010

3. Malta DC, Oliveira MR, Moura EC, Silva AS, Zouain CS, Santos FP, et al. Fatores de risco e proteção para doenças crônicas não transmissíveis entre beneficiários da saúde suplementar: resultados do inquérito telefônico Vigitel, Brasil, 2008. Ciênc Saúde Colet. 2011; 16(3):2011-22. doi: 10.1590/S1 413-81232011000300035

4. Malta DC, Silva Junior JB. O plano de ações estratégicas para o enfrentamento das doenças crônicas 
não transmissíveis no Brasil e a definição das metas globais para o enfrentamento dessas doenças até 2025: uma revisão. Epidemiol Serv Saúde. 2013; 22(1):151-64. doi: 10.5123/S1679-49742013000 100016

5. Assis MAA, Calvo MCM, Kupek E, Vasconcelos FAG, Campos VC, Machado M, et al. Qualitative analysis of the diet of a probabilistic sample of schoolchildren from Florianópolis, Santa Catarina State, Brazil, using the Previous Day Food Questionnaire. Cad Saúde Pública. 2010; 26(7): 1355-65. doi: 10.1590/S0102-311X2010000700 014

6. Costa LCF, Vasconcelos FAG, Corso ACT. Fatores associados ao consumo adequado de frutas e hortaliças em escolares de Santa Catarina, Brasil. Cad Saúde Pública. 2012; 28(6):1133-42. doi: 10.1590/S0 102-311X2012000600012

7. Costa FF, Assis MAA, Leal DB, Campos VC, Wolney EK, Conde L. Mudanças no consumo alimentar e atividade física de escolares de Florianópolis, SC, 2002-2007. Rev Saúde Pública. 2012; 46(Supl): 117-25. doi: 10.1590/S0034-89102012005000 058

8. Instituto Brasileiro de Geografia e Estatística. Pesquisa nacional de saúde do escolar 2009. Brasília: IBGE; 2009 [acesso 2013 jun 15]. Disponível em: <http://www.ibge.gov.br/home/estatistica/ populacao/pense/pense.pdf>.

9. Riediger ND, Shooshtaris S, Moghadasian MH. The influence of sociodemographic factors on patterns of fruit and vegetable consumption in Canadian adolescents. J Am Dietetic Assoc. 2007; 107(9): 1511-8. doi: 10.1016/j.jada.2007.06.015

10. Pérez-Lizaur AB, Kaufer-Horwitz M, Plazas M. Environmental and personal correlates of fruit and vegetable consumption in low income, urban Mexican children. J Hum Nutr Diet. 2008; 21(1): 63-71. doi: 10.1111/j.1365-277X.2007.00839.x

11. Levy RB, Castro IRR, Cardoso LO, Tavares LF, Sardinha LMV, Gomes FS, et al. Consumo e comportamento alimentar entre adolescentes brasileiros: Pesquisa Nacional de Saúde do Escolar (PeNSE) 2009. Ciên Saúde Colet. 2010; 15(Supl 2):3085-97. doi: 10.1590/S1413-81232010000800013

12. Instituto Brasileiro de Geografia e Estatística. Pesquisa Nacional de Saúde do Escolar - PeNSE 2012. Rio de Janeiro: IBGE; 2013 [acesso 2014 mar 24. Disponível em: <http://www.ibge.gov.br/home/ estatistica/populacao/pense/2012/pense_2012. pdf $>$.

13. Bernardo CO, Vasconcelos FAG. Association of parents' nutritional status, and sociodemographic and dietary factors with overweight/obesity in schoolchildren 7 to 14 years old. Cad Saúde Pública.
2012; 28(2):291-304. doi: 10.1590/S0102-31 1X2012000200008

14. Vasconcellos MB, Anjos LA, Vasconcellos MTL. Estado nutricional e tempo de tela de escolares da rede pública de ensino fundamental de Niterói, Rio de Janeiro, Brasil. Cad Saúde Pública. 2013; 29(4): 713-22. doi: 10.1590/50102-311X2013000400 009

15. Pizarro JV, Royo-Bordonada MA. Prevalence of childhood obesity in Spain: National Health Survey 2006-2007. Nutr Hosp. 2012; 27(1):154-60. doi: 10.1590/S0212-16112012000100018

16. Brasil. Ministério da Saúde. Análise da estratégia global da organização mundial da saúde para alimentação saudável, atividade física e saúde. Brasília: Ministério da Saúde; 2004 [acesso 2013 maio 29]. Disponível em: <http//www.saude.gov.br/ alimentacaos.

17. Brasil. Ministério da Saúde. Guia alimentar para a população brasileira: promovendo a alimentação saudável. Brasília: Ministério da Saúde; 2006 [acesso 2013 jun 29]. Disponível em: <http://189.28.128.1 00/nutricao/docs/geral/guia_alimentar_conteudo. $\mathrm{pdf}>$.

18. World Health Organization. Fruit, vegetables and NCD disease prevention. Geneva: WHO; 2003 [cited 2013 Jun 27]. Available from: <htto//www.who.int/ hpr/gs.fruit.and.vegetables.shtm1>.

19. Basch CE, Zybert P, Shea S. 5-A-day: Dietary behavior and the fruit and vegetable intake of Latino children. Am J Public.1994; 84(5):814-8.

20. Havas S, Heimendinger J, Damron D, Nicklas TA, Cowan A, Beresford SAA, et al. 5-A-Day for better health-nine community research projects to increase fruit and vegetable consumption. Public Health Rep. 1995; 110(1):68-79.

21. Abrantes MM, Lamounier JA, Colosimo EA. Comparison of body mass index values proposed by Cole et al. (2000) and Must et al. (1991) for identifying children with weght-for-height index recommended by the World Health Organization. Public Health Nutr. 2003; 6(3):307-11. doi: 10.10 79/PHN2002426

22. Salles RK, Kazapi IAM, Di Pietro P. Ocorrência de obesidade em adolescentes da rede de ensino do município de Florianópolis. In: Oliveira JED, Lamounier JA, Assis AMO, Berezovsky MW, Portella Junior. AO, organizadores. Anais do simpósio: obesidade e anemia carencial na adolescência. São Paulo: Instituto Danone; 2000. p.21.

23. World Health Organization. Physical status: The use and interpretation of anthropometry. Geneva: WHO; 1995 [cited 2013 Jun 29]. Technical Report Series, $n^{\circ} 854$. Available from: <http://www.who. int/childgrowth/publications/physical_status/en/>. 
24. Lohman TG, Roche AF, Martorell R. Antropometric standardization reference manual. Champaign (IL): Human Kinetics; 1988.

25. Frainer DES, Adami F, Vasconcelos FAG, Assis MAA, Calvo MCM, Kerpel R. Padronização e confiabilidade das medidas antropométricas para pesquisa populacional. Arc Latinoam Nutr. 2007; 57(4):335-42.

26. Cole TJ, Bellizi MC, Flegal KM, Dietz WH. Establishing a standard definition for child overweight and obesity worldwide: International survey. BMJ. 2000; 320(7244):1240-3. doi: 10.1136/bmj.320. 7244.1240

27. Assis MAA, Benedet J, Kerpel R, Vasconcelos FAG, Di Pietro PF, Kupek E. Validação da terceira versão do Questionário Alimentar do Dia Anterior (QUADA-3) para escolares de 6 a 11 anos. Cad Saúde Pública. 2009; 25(8):1816-26. doi: 10.1590/ S0102-311X2009000800018

28. Toral N, Slater B, Silva MV. Consumo alimentar e excesso de peso de adolescentes de Piracicaba. Rev Nutr. 2007; 20(5):449-59. doi: 10.1590/S1415-52 732007000500001

29. Fagundes ALN, Ribeiro DC, Naspitz L, Garbelini LEB, Vieira JKP, Silva AP, et al. Prevalência de sobrepeso e obesidade em escolares da região de Parelheiros do município de São Paulo. Rev Paul Pediatr. 2008;
26(3):212-17. doi: 10.1590/S0103-05822008000 300003

30. Hassapidou M, Fotiadou E, Maglara E, Papadopoulou SK. Energy intake, diet composition, energy expenditure, and body fatness of adolescents in northern Greece. Obesity. 2006; 14(5):855-62.

31. Godoy FC, Andrade SC, Morimoto JM, Carandina L, Goldbaum M, Barros MBA, et al. Índice de qualidade da dieta de adolescentes residentes no distrito do Butantã, município de São Paulo, Brasil. Rev Nutr. 2006; 19(6):663-71. doi: 10.1590/S1415-52 732006000600003

32. Kristjansdottir AG, Thorsdottir I, Bourdeaudhuij I, Due P, Wind M, Klepp KI. Determinants of fruit and vegetable intake among 11-year old schoolchildren in a country of traditionally low fruit and vegetable consumption. Int J Behav Nutr Phys Act. 2006; 3(41):1-9. doi: 10.1186/1479-5868-3-41

33. Matos SMA, Rodrigues MLBLC, Oliveira VA, Oliveira LPM, D'Innocenzo S, et al. Padrões alimentares de crianças menores de cinco anos de idade residentes na capital e em municípios da Bahia, Brasil, 1996 e 1999/2000. Cad Saúde Pública. 2014; 30(1):44-54. doi: 10.1590/0102-311X00164712

Received on: 8/29/2013

Final version on: $4 / 30 / 2014$

Approved on: 5/19/2014 